\author{
Ю. А. Артамонов \\ Московский университет МВА России им. В. Я. Кикотя, ИРИ РАН, ИВИ РАН, Москва, Россия. \\ Artamonov5@yandex.ru
}

\title{
О ВРЕМЕНИ СОВЕРШЕНИЯ АРХИЕРЕЙСКИХ ИНТРОНИЗАЦИЙ В АРЕВНЕЙ РУСИ
}

\begin{abstract}
На основе анализа источников делается вывод о том, что в Аревней Руси существовала практика совершения местных интронизаций, которая распространялась и на русских епископов, поставляемых в Киеве, и на митрополитов, прибывающих из Византии. Как и хиротония, возведение архиерея на свой стол подготавливалось заранее и совершалось мибо в воскресенье, мибо в день большого церковного праздника. Наличие этой закономерности требует более внимательного отношения к тем хронологическим указаниям источников, которые Аатируют посажения епископов будними Анями. С опорой в том числе и на это заключение автор преАлагает Аатировать вступление на Новгородскую кафеАру владыки Иоанна Попьяна не 20 Аекабря 1110 г. (как принято считать в митературе), а 20 декабря 1108 г., когда указанный день приходияся на воскресенье.

Ключевые слова: интронизачия, настолование, епископ, митрополит, древнерусские епархии, древнерусскал церковь, хронология древнерусского летописания
\end{abstract}

За содействие в подготовке настоящей статьи автор благодарит А. Ю. Виноградова, Т. В. Гимона, М. В. Печникова.

Памяти Анджея Поппэ посвящается

Восприятие кафеАры как ритуального символа епископского служения формировалось в первые века распространения христианства поА воздействием традиций властной практики Рима и отчасти раввинистического иудаизма. В результате этой сакрализации возникло особое священнодействие - посажение архиерея на трон (кафеАру), которое стало частью обряда хиротонии. Первые письменные свидетельства его существования относятся к IIIIV в. Например, в митургико-каноническом памятнике «Апостольские постановления» (Constitutiones apostolicae), составленном около 380 г., отмечается, что рукоположенного епископа наутро следует возвести «на принадлежащий ему престол», после чего «приветствовать целованием о Господе» ${ }^{1}$. 3Аесь обряды хиротонии и посажения на кафеАру разнесены по времени, что говорит о росте значения последнего [Желтов, с. 124].

В Византийской церкви рукоположение и интронизация первоначально совершались в кафеАральном центре будущего служения архиерея. Эту практику имел в виду святитель Симеон Солунский (ум. 15 сентября 1429 г.), когАа писал, что в былые времена «архиерея сажали на престол при собрании епископов», которые действовали в соответствии суказанием «архиепископа». Со временем, по причине «постигших церковь искушений, смятений и набегов варваров», хиротонии и возведения на кафеАру стали совершаться «только в одной Великой Церкви», то есть в соборе Св. Софии в Константинополе ${ }^{2}$. ОАнако интронизация во время рукоположения не могла заменить посажения на собственной кафедре. Это привело к возникновению традиции «особого священнодействия» по возвращении архиерея в свою епархию, которое в определенной степени дублировало «уже совершенную во время хиротонии церемонию восседания» [Желтов, с. 126; Несемовский, с. 245-246].

${ }^{1}$ Апостольские постановления. Кн. VIII/5 [Электронный ресурс]. URL: www. azbyka.ru/otechnik/6/apostolskiepostanovlenija (Аата обращения: 17.01.2020). В этом же сочинении впервые фиксируется особый митургический термин Аля обозначения посажения архиерея на его место - «интронизовать $\gg(\mathcal{\varepsilon} v \theta \rho o v i \zeta \varepsilon v)$.

2 Patrologia Graeca. Paris, 1866. T. 155. Col. 428-429. 3Аесь и Аалее перевод мой.

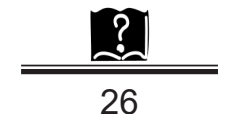


Согласно Симеону Солунскому, интронизация совершалась в церкви при участии Ауховенства и мирян. По прочтении молитвы и Трисвятого первый или второй из священников трижАы усаживац рукоположенного святителя на кафеАру, при этом каждый раз возглашая: «Аксиос» (от греч. ״̊’ Іо - 'Аостоин'). Затем следовало многолетствие властям и самому виновнику торжества. После отпуста момящиеся поАходили к архиерею Аля поцекуя руки и получения благословения. Завершалась церемония трапезой и торжественным выездом новопосвященного епископа Амя благосмовения города и его житемей ${ }^{3}$.

Нужно полагать, что обряА интронизации был воспринят на Руси вскоре после официального принятия христианства. ЗАесь он получия название «настолование» или «посажение на стол» [Евгений (Болховитинов), с. 15; Макарий (Булгаков), с. 537-538]4. ОАним из первых о нем упоминает киевский митрополит Иларион (сереАина XI в.). В приписке к его сочинениям читаем: «Аз милостию человеколюбивааго Бога, мних и прозвитер Ияарион, изволением Его от богочестивых епископ священ бых и настолован в велицем и богохранимем граде Кыеве, яко быти ми в немь митрополиту, пастуху же и учителю. Быша же си в мето 6559, владычествующу благоверьному кагану Ярославу сыну Вцадимирю. Аминь $\gg^{5}$. О настоловании епископов сообщает и проложное Сказание об освящении церкви святого Георгия в Киеве (26 ноября), построенной иждивением князя Ярослава ВАадимировича (1019-1054): «И с(вя)ти ю Аариономь митрополитомь м (е)с (я)ца ноября въ 26 А(е)нь и створи въ неи

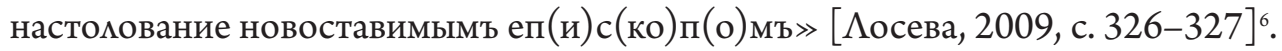

Сажали на кафеАру не только русских архиереев, но и святителей, прибывавших из Византии. Весьма показательно в этом смысле сообщение $\Lambda$ аврентьевской метописи (Аалее -

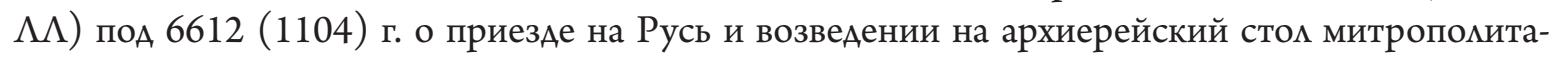
грека Никифора. Первое событие датировано 6 декабря, второе - 18 декабря: «...том же

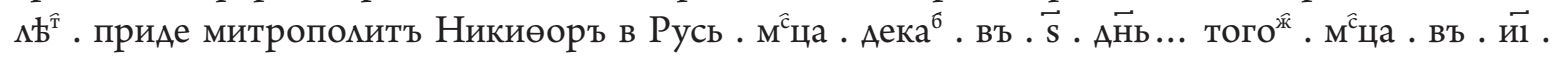
Никиөоръ митрополитъ на столь посаженъ »7. Как видно, дата приезАа иерарха не совпадает с Аатой его возведения на кафеАру. И это понятно: организация интронизации требоваца времени. В частности, необходимо было обеспечить присутствие епископов, которые, хотя и оповещались о прибытии митрополита заранее ${ }^{8}$, но не всегда могли своевременно добраться Ао Киева. ПоА 6732 (1224) г. та же метопись сообщает: «Поставленъ бы ${ }^{\mathrm{\imath}}$ митрополитомь .

\footnotetext{
3 Ibid. Впрочем, при совершении чина посажения могли наблюдаться и некоторые региональные особенности [Желтов, с. 126].

Недавно было высказано мнение, что «настолование» и «посажение на стол» суть вещи разные. «Настолование» представмяло собой собственно интронизацию, которая совершалась сразу или вскоре после рукоположения архиерея, а «посажение на стол» явмялось своеобразным «актом переАачи ему его резиленции». «Таким образом выражение състи на столъ в отношении иерархов, как и в отношении князей, указывало не на богослужебный чин, а на акт утверждения иерарха в своей резиденции, что означало его официальное вступление в Аолжность» [Виноградов, Желтов, с. 161]. ОАнако аргументация, предлагаемая исследователями, не выглядит убедительной. Мне кажется, что посажение на стол представляло собой именно священнодействие, которое, если и не воспроизводимо чин интронизации полностью, то было очень к нему близко. Иначе трудно объяснить передаваемые цетописцами факты встречи новопоставленных архиереев духовенством и мирянами города с крестами, свечами и кадилами, исполнение церковных песнопений, посещение соборного храма. Амя «утвержАения иерарха в своей резиденции» хронисты использовали иные выражения: «ввести в церковь», «ввести во Авор», «посадить во Аворе» (ПСРА. М., 2001. Т. 1. Стб. 453; М., 2000. Т. 3. С. 216, 232, 239, 275 ). Причем (и это важно!) переАача резиденции происходила Ао совершения хиротонии, а не послеАовала ей.

5 БААР. СПб., 1997. Т. 1. ХІ-ХІІ века. С. 60. Как отмечает А. А. Туримов, «именование киевского князя каганом, свойственное памятникам письменности XI в., свидетельствует о раннем происхождении Аанного текста» [Турилов, с. 122].

${ }^{6}$ Настоящий пассаж, как полагает Ю. А. Виноградов, нужно понимать в том смысле, что вскоре после освящения церкви св. Георгия в ней состоялась интронизация нескольких архиереев [Виноградов]. Благодарю АнАрея Юрьевича, который Аюбезно предоставил мне текст своей работы.

7 ПСРА. Т. 1. Стб. 280.

${ }^{8}$ Рассказывая о приходе новгородского епископа Нифонта в Киев, метописец сообщает: «... башеть бо ему въсть . гко оуже . пошемъ есть митрополитъ» (ПСРА. М., 2001. Т. 2. Стб. 483).
}

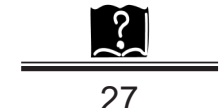




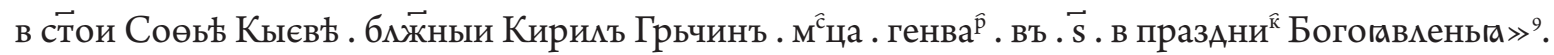
Поскольку Кирим I был рукоположен в Никее патриархом Германом II (1222-1240), «поставление» в стенах киевской Софии явмялось не чем иным, как посажением на стол [Поппэ, с. 464].

Иетописные известия говорят о том, что возведение на кафеАру было важным событием в жизни Ауховных центров Аревней Руси: встречи новопоставленныхиерархов сопровожАались многолюАными шествиями, в которых, как правило, принимали участие князья, боярство, Ауховенство и простые горожане. Архиерея встречали на некотором расстоянии от города с крестами, свечами и кадилами. Затем процессия с церковными песнопениями вступала в гороА через главные ворота и следовала в кафедральный храм, где в ходе богослужения совершался обряд воссеАания ${ }^{10}$.

Полагаю, что Аля организации этих церемоний власти Аолжны были определять особое время. Из византийских источников, например, известно, что хиротонию преАписывалось совершать в воскресенье ${ }^{11}$. Аругие Ани недели могли назначаться только в том случае, если они совпадали с большими церковными торжествами - Авунадесятыми или так называемыми Великими праздниками. Анализ метописных датированных сообщений XIV-XV в. позволил Н. С. Борисову саелать вывоА, что это правило отчасти действовало и на Руси ${ }^{12}$. Можно ли Аумать, что выбор дня местной интронизации на Руси определялся тем же порядком?

Аля ответа на этот вопрос рассмотрим свидетельства источников Аомонгольского периода о прибытии или посажении на Аревнерусские кафедры новопоставленных архиереев, которые имеют точные Аневные Аатировки. Таких свидетельств сравнительно немного, всего 17. Приведем их в хронологической последовательности.

Muтрополит Никифор I (1104-1121). $\Lambda$ поА 6612 (1104) г.: «том же $\Lambda \mathrm{b}^{\hat{T}}$. приде

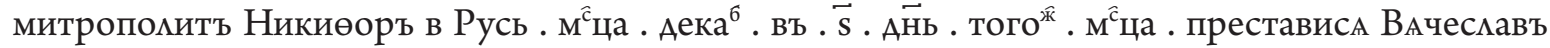

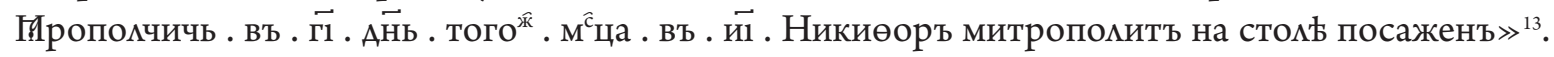
Киевский митрополит Никифор I прибыл в столицу Руси во вторник 6 декабря 1104 г., а спустя 12 Аней, 18 декабря был возведен на кафеАру. В 1104 г. этот Аень был воскресным.

Новгородский епископ Иоанн Попьян (1110-1130). Новгородская первая метопись младшего извода (Аалее - НП м м.) под 6618 (1110) г.: «Прииде в Новъгород архиепископъ Иоанн, мъсяца декабря въ 20»14. В 1110 г. 20 Аекабря приходимось на вторник.

Черниговский епископ Феоктист (1113-1123). ИА ПоА 6620 (1112) г.: «исхоААщю Же сему мъту и поставиша Фешктїста епп̆комъ Чернъгову . игумена Печерьскаго . м̊ца генварА .

\footnotetext{
ПСРА. Т. 1. Стб. 447.

10 Наиболее обстоятельный рассказ о совершении местной интронизации содержится в статье 6739 (1231) г. $\Lambda \Lambda$, повествующей о поставлении на кафедру ростовского епископа Киримла II: «Изидоша же вси из града бохранимаго Ростова . кнАЗิ Василко . и кнагини єго . и богаре . и вси мужи Ростовьскиђ . игумени же и попове

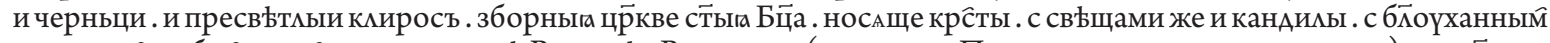
темьґном . и быс радос велика в градђ Ростовђ . ВывеАоша (примеч. г: По смыслу ожидается въведоша) же сщнаго

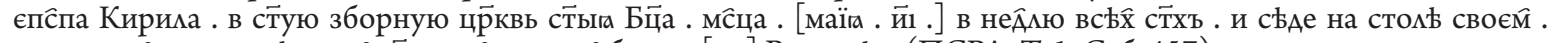

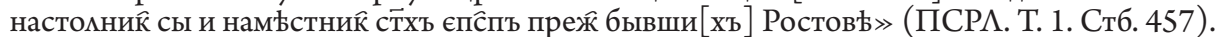

11 «о наступлении воскресного Аня в церковь собираются все архиереи, участвовавшие в избрании. Приходит и архиепископ Аля совершения рукоположения вместе с ними ... » (Patrologia Graeca. Col. 408).

12 «Интересно, - отмечает исследователь, - что при распределении точно Аатированных событий XIV-XV вв. по Аням недели можно заметить некоторые закономерности. К воскресным Аням чаще всего приурочивались поставления епископов и митрополитов» [Борисов, с. 130-131]. По мнению А. В. Ааушкина, внимание метописцев к хронологии поставления архиереев определялось «канонической каленАарно-обрядовой необходимостью», а именно: празднованием Аня хиротонии в качестве епархиального торжества [Ааушкин, 2004, с. 103].

13 ПСРА. Т. 1. Стб. 280. В Ипатьевской метописи (Аахее - ИА) Аень посажения Никифора на стол не указан (ПСРА. Т. 2. Стб. 256).

${ }^{14}$ ПСРА. Т. 3. С. 203.
}

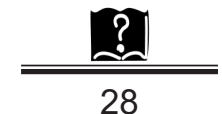




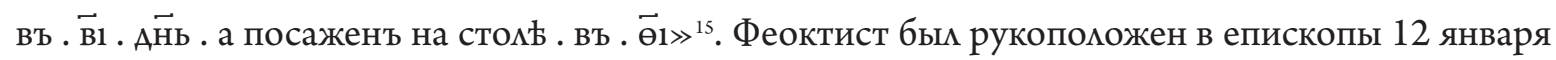
1113 г. в Киеве, а через неделю, 19 января, возведен на кафеАру черниговских архиереев. 12 и 19 января в 1113 г. были воскресными Анями.

Киевский митрополит Никита (1122-1126). $\Lambda \Lambda$ поА 6630 (1122) г.: «престависА єп ${ }^{\hat{c} п ъ ~}$

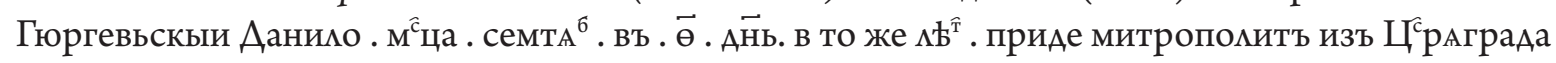
въ стую Соөью . имене ${ }^{\widehat{\hat{n}}}$ Никита» ${ }^{16}$. Ни один из дошедших до нас метописных сводов не называет календарной даты вступления Никиты на митропомичью кафеАру. Но ее, как принято

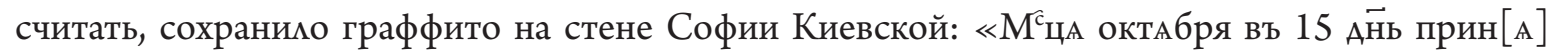
$\Lambda$ ъ Никита ... » [Высоцкий, с. 38] ${ }^{17}$. Вероятность такой Аатировки подтвержАает относительная хронология погодной статьи, согласно которой митрополит пришел «в святую Софию» после 9 сентября (время преставления юрьевского епископа Ааниима). 15 октября в 1122 г. приходилось на воскресенье.

Переяславский епископ Марк (1125-1134). $\Lambda \Lambda$ поА 6634 (1126) г.: «Постави кнАзь

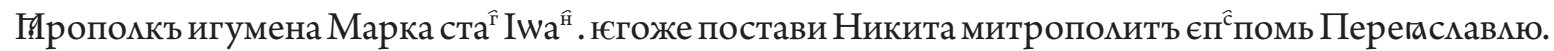

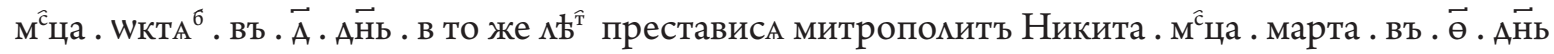

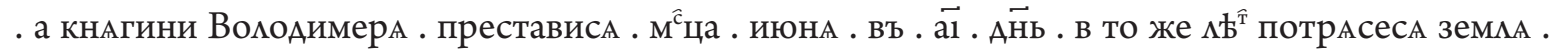

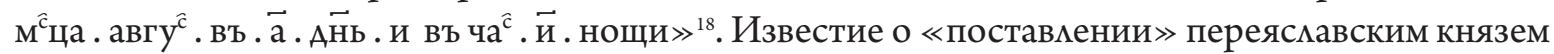
Ярополком (1114-1132 г.) епископа Марка опережает события, которые хронологически Аолжны были ему предшествовать (9 марта, 11 июня, 1 августа), что указывает на его вставной характер. По всей видимости, как отмечац Н. Г. Бережков, в источнике, откуда Аанное сообщение было заимствовано, оно Аатировалось сентябрьским годом ${ }^{19}$. Октябрь 6633 мартовского года соответствует 6634 сентябрьскому году. Этого не учел сводчик, который поместил известие о Марке в мартовскую статью, помеченную тем же «цифровым обозначением», а «не в предшествующую статью, гАе при метописном счете мартовскими годами ему было бы место по его действительной дате» [Бережков, с. 50]. Таким образом, возведение Марка на Переяславскую кафеАру произошло в 1125 г. Тогда 4 октября приходилось на воскресенье.

Новгородский епископ Нифонт (1130-1156). НП М мл. поА 6638 (1130) г.: «Того же $\Lambda$ бта отвержеся архиепископъ Иоанн новгородчкыи, съАъ $\Lambda$ Ђт 20, и поставиша архиепископа Нифонта, мужа свята и зъло боящася бога; и прииде Новугороду мъсяца генваря въ 1 день, на святого Василья, на объднюю» ${ }^{20} .1$ января совершалась память святитемя Василия Великого; в 1131 г. этот день приходияся на четверг.

Новгородский епископ Аркадий (1158-1164²1). НПА мА. поА 6666 (1158) г.: «Того же поиде Аркадии къ Кыеву ставится епископомъ, и поставленъ бысть от митрополита Костянтина, и прииде в Новъгород, мъсяца семтября въ 13 день, на канунъ святого ВъзАвижениа»22. 13 сентября был Анем, предшествующим большому церковному празднику Воздвижения честного и животворящего Креста. В 1158 г. канун этого торжества приходияся на субботу, а сам праздник - на воскресенье.

15 ПСРА. Т. 2. Стб. 274. В М отмечается томько время рукоположения - 11 января 1113 г. В этом году указанная Аата приходимась на субботу, что говорит о ее недостоверности (ПСРА. Т. 1. Стб. 289).

${ }^{16}$ ПСРА. Т. 1. Стб. 292. ИА не называет камендарных дат преставмения юрьевского епископа Ааниима и посажения Никиты (ПСРА. Т. 2. Стб. 286).

17 Интерпретация С. А. Высоцкого получима подАержку исследоватемей [Щапов, с. 191, 195; Поппэ, с. 453].

18 ПСРА. Т. 1. Стб. 296. В ИА о посажении Марка Переяславского ничего не сообщается. По мнению А. Ю. Карпова, в Аанном случае метописец говорит не о хиротонии, а о возведении епископа Марка на Переяславскую кафеАру [Карпов, с. 275, 499].

19 Мнение Н. Г. Бережкова подтвержАает то, что сентябрьский стиль, бытовавший тогАа в Византии, нереАко использовался митрополией и кафедрами (ср. Аатировку «Смоленских грамот»).

${ }^{20}$ ПСРА. Т. 3. С. 207.

21 Такая датировка кончины святителя следует из его Жития, в метописи указан 1163 г. [Карпов, с. 58-59].

${ }^{22}$ ПСРА. Т. 3. С. 217.

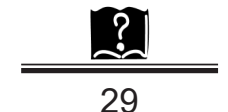


Новгородский епископ Илья (1165-1186). НПА мл. поА 6673 (1165) г.: «Поставленъ бысть Илья архиепископъ новгородчкыи от митрополита Иоана, при великом князъ рустьмь Ростиславъ, марта въ 28, на вербьницю, и прииде к Новугороду мая въ 11 день, при князъ Святославъ, а при посадниц Захарьи»²3. «Вербницей» метописец называет большой христианский празАник - ВхоА Господень в Иерусалим (иначе - Вербное воскресенье), который отмечается в 6-е воскресенье Великого поста. В 1165 г. этот день выпадал на 28 марта. Спустя примерно полтора месяца, 11 мая Илья вернулся в НовгороА. Этот Аень в 1165 г. приходился на вторник.

Новгородский епископ Гавриил (1187-1193). НПА мм. поА 6695 (1187) г.: «Поставменъ бысть архиепископомъ новгородчкымъ Гаврила въ 29 марта, а прииде к Новугороду мая въ 31; и ради быша новгородци своему владыць» 24 . В 1187 г. 29 марта - Аата хиротонии Гавриила и 31 мая - Аата его встречи новгородцами были воскресными Анями.

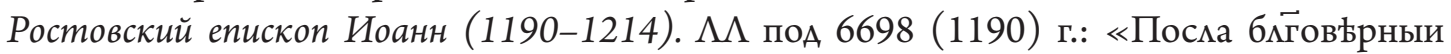
хр ${ }^{\hat{\imath}}$ олюбивыИ великыи кнАзь Всеволодъ снъъ Гюргевъ . внукъ Мономаховъ Володимерь г Кыєву. СТославу ко Всеволодичю . и к митрополиту Никиөору . ШЦА своюго АхВ̈наго Iwa ${ }^{\hat{n}}$ . на ЄП ${ }^{\hat{c}}$ пьство... ХотАщю юго Поставити служителА своєи црркви . и Пастуха всеи земли .

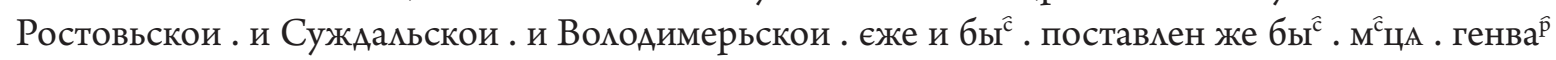

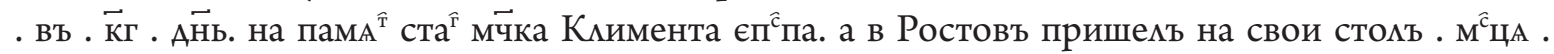

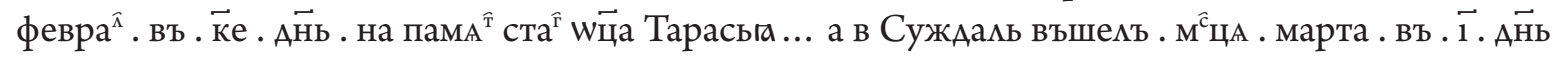

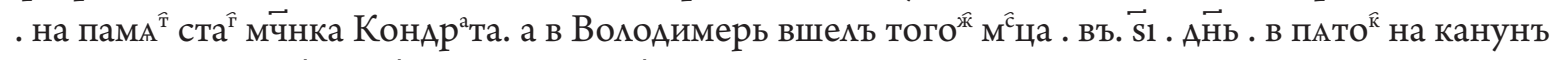

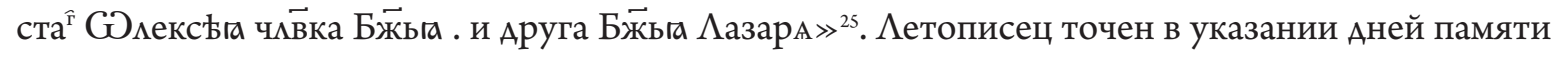
святых: 23 января церковь вспоминаца священномученика Климента Анкирского, 25 февраля святителя Тарасия Константинопольского, 10 марта - святого мученика КоАрата Коринфского и, наконец, 16 марта был Анем, предшествующим памяти преподобного Алексия, человека Божия. Хронист уточняет, что во ВАаАимир новопоставленный архиерей прибыи «в пяток», то есть в пятницу. Поскольку 16 марта приходилось на пятницу в 1190 г., можно говорить об использовании здесь ультрамартовского стиля, в целом характерного Аля данной части $\Lambda \Lambda$. В этом году 25 феврамя - день вступления Иоанна в Ростов - был воскресным. В Аругие города земли архиерей приезжал в будни: СузАаль встречал Иоанна в субботу, а Владимир - в пятницу. Такая хронология объясняется тем, что посещение последних Авух городов не преАполагало совершения обряда посажения на стол, который состоянся в Ростове - кафедральном центре епархии.

Новгородский епископ Мартирий (1193-1199). НПА мА. поА 6701 (1193) г.: «...И поставиша и (Мартирия. - Ю. А.) декабря въ 10, на память святых мученикъ Мины и Ермогена и Еуграфа; и прииде в Новъгород генваря въ 16, на поклонение честных веригъ святого апостола Петра» ${ }^{26}$. Аень покмонения веригам апостола Петра отмечался 16 января; в 1194 г. он приходился на воскресенье.

Новгородский епископ Митрофан (1201-1223, с перерывами). НПА мл. поА 6709 (1201) г.: «Новъгородьци богомь избранаго Митрофана въведоша въ епископью по Мартурии, и иде въ Русь ставитъся къ митрополиту... и поставленъ бысть мъсяця июмя въ 3 день, на святого Уакинфа; и приде въ Новъгородъ септября въ 14, на Въздвижение честьнаго хреста; и ради

23 Там же. С. 219.

24 Там же. С. 229. НП А с. Аополняет Аанное известие указаниями на Ани памяти святых: Щоставленъ бысть архиепископъ новгородьскыи Гаврияа мъсяця марта въ 29, на святого Варихисия, и приде Новугороду мъсяця маия въ 31, на святого мученика Ермиа; и ради быша новъгородьци» (Там же. С. 38 ).

25 ПСРА. Т. 1. Стб. 408.

${ }^{26}$ ПСРА. Т. 3. С. 232. НП А ст. Аопускает хронологическую неточность: «...И поставиша и мьсяця декабря въ 10 , на святого Аанила стълъпника; и приде въ Новъгородъ мъсяця генваря въ 16, на святого апостола Петра съпадение веригамъ» (Там же. С. 40). Память Ааниияа Столпника праздновалась не 10, а 11 декабря.

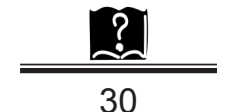


быша новгородьци своему вмадыць $2^{27} .14$ сентября церковь отмечала праздник ВозАвижения Честного и Животворящего Креста, принадлежащий к чиску Авунадесятых.

Новгородский епископ Митрофан (1201-1223, с перерывами) ${ }^{28}$. НП А ми. поА 6728 (1219) г.: «Прииде архиепископъ Митрофанъ, оправивъся богомъ и святою Софъею, в Новъгород марта въ 17, на память святого отца нашего Семеона иже в ПерсиАъ $\gg^{29}$. Аетопись допускает неточность: священномученика Симеона ПерсиАского церковь вспоминала не 17 марта, а 17 апремя ${ }^{30} .17$ марта в 1219 г. было воскресным Анем ${ }^{31}$.

Ростовский епископ Пахомий (1214-1216). $\Lambda \Lambda$ поА 6722 (1214) г.: «Того КостАнтинъ посла Пахомьг . игумена ста ${ }^{\hat{R}}$ Петра . шца своюго АхВНнаго в Кыєвъ к митрополиту Матфъю . и постави и єп ${ }^{\hat{c} п м ъ ~ Р о с т о в у ~ . ~ н о г б р А ~ . ~ в ъ ~ . ~} \overrightarrow{1}$. и въниде в свою єп . на пам $A^{\hat{T}}$ ста ${ }^{\hat{T}}$ Wца . Єфрьма Сурина $\gg^{32}$. Память преподобного Ефрема Сирина празАновалась 28 января; в 1215 г. этот день приходияся на средуз

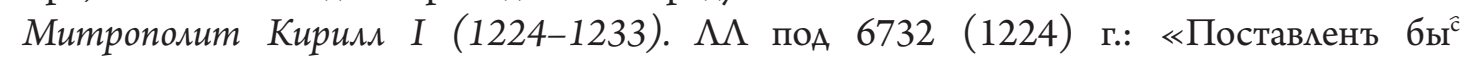

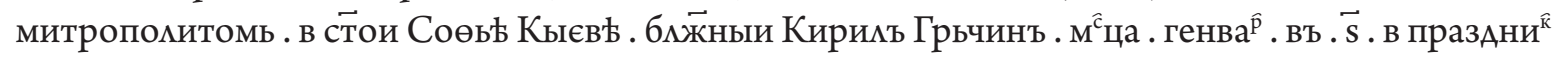
Богогвменьга $\gg^{34} .6$ января церковь отмечама Богоявмение Господне - один из Авунадесятых праздников, установленных в честь крещения Иисуса Христа в водах ИорАана.

Новгородский епископ Спиридон (1230-1249). НП М м.. поА 6738 (1230) г.: «Того же $\Lambda$ bта солнче померче мая въ 14, вторник, на память святого мученика Сидора, в полъутра, и бысть яко 5 ночеи мъсяць, и пакы опять наполнися помалу, и ради быхомъ маловъръи. Того же мъсяца на зборъ, въ 19, на память святых отець 300 и 18, прииде в Новъгород архиепископъ Спуридонъ, поставленъ бысть от митрополита Кирила в попы в сыропустную неАБлю,

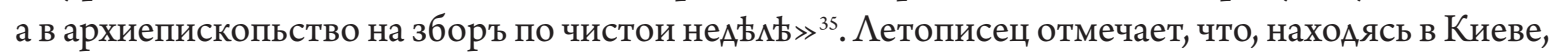
Спиридон быц «в сыропустную недьцю» рукоположен в священники, а затем «на зборъ по чистои неАъ $\Lambda \mathrm{b} \gg-$ в епископы. Сыропустная недемя - последнее воскресенье переА Великим постом и Соборная недемя - первое воскресенье Великого поста в 1230 г. приходились на 17 и 24 феврамя соответственно. Спустя почти Ава месяца, 19 мая Спиридон вошел в Новгород ${ }^{36}$. В указанном году этот день был воскресным.

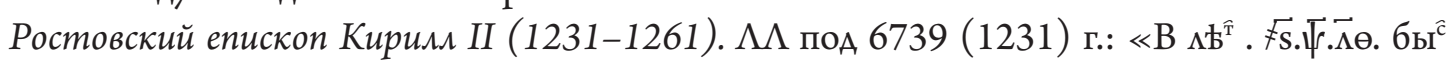

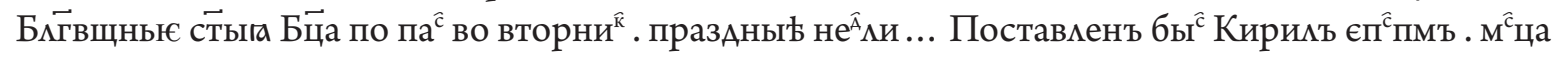

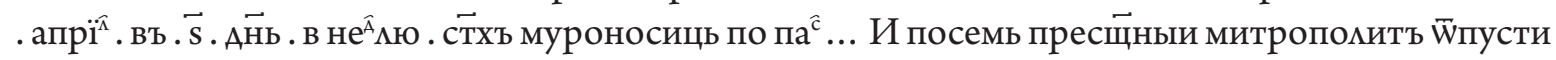

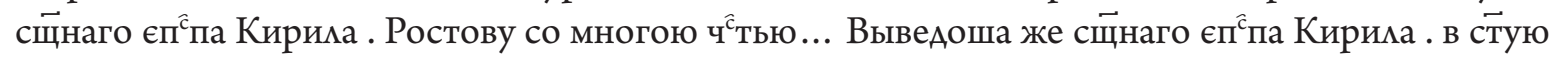

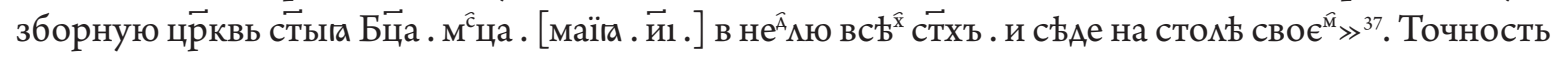
хронологических указаний метописи в Аанном случае не вызывает сомнений. Благовещение пресвятой Богородицы праздновалось 25 марта, в 1231 г. этот Аень, Аействительно, приходился на вторник. Кирим был рукоположен в Аень жен-мироносиц, а посажен на Ростовскую кафеАру

\footnotetext{
${ }^{27}$ ПСРА. Т. 3. С. 239.

28 Архиепископ Митрофан дважды вступал на Новгородскую кафеАру. ВзойАя на стол 14 сентября 1201 г., он был мишен его в начале 1210 г. На несколько мет кафедру занял владыка Антоний. В 1220 г. митрополит Матфей разрешил спор иерархов в пользу Митрофана, который повторно сел на стол 17 марта того же гоАа.

${ }_{29}$ ПСРА. Т. 3. С. 261.

30 Аумаю, что в Аанном случае указание на день памяти явмяется более поздней вставкой.

${ }_{31}$ Статья 6728 г. явмяется умьтрамартовской [Бережков, с. 251, 260].

${ }^{32}$ ПСРА. Т. 1. СТб. 438.

33 Общепризнанное отнесение хиротонии Пахомия к 1214 г., а посажения на кафеАру - к 1215 г. явмяется ошибочным. На самом деле, в Киеве ростовский архиерей ставился 10 ноября 1213 г. (в воскресенье!), а в Ростов вошел кибо в конце того же гоАа, мибо в начале 1214 г. (Этой проблеме автор планирует посвятить отдельную работу.)

34 ПСР $\Lambda$. Т. 1. Стб. 447.

${ }^{35}$ ПСРА. Т. 3. С. 276.

36 ЗАесь допущена ошибка: память I Вселенского собора праздновалась не 19, а 29 мая.

${ }^{37}$ ПСРА. Т. 1. Стб. 456-457.
} 
в день всех святых. Оба праздника отмечаются в воскресенья: первый через две, а второй через восемь недель после Пасхи. В указанном году эти памятные Ани приходились на 6 апремя и 18 мая соответственно.

МежАу центрами епархий показания источников о прибытии или посажении новопоставленных архиереев распределяются таким образом: Новгород - 9, Киев - 3, Ростов 3 , Чернигов - 1 , Переяславль - 1. По Аругим кафеАрам известия отсутствуют, что объясняется утратой памятников местной метописной традиции, которые преимущественно и фиксировали события такого рода. Результаты проведенного анализа преАставлены в следующих таблицах.

Новгород

\begin{tabular}{|c|c|c|c|}
\hline \multirow[t]{2}{*}{$\Pi / \Pi$} & \multirow{2}{*}{$\begin{array}{l}\text { Имя архиерея } \\
\text { и период его правмения }\end{array}$} & \multicolumn{2}{|l|}{ Настолование } \\
\hline & & Аата & Аень неАели \\
\hline 1. & Иоанн Попьян (1110-1130) & 20 декабря 1110 г. & Вторник \\
\hline 2. & Нифонт (1130-1156) & 1 января 1131 г. & Четверг \\
\hline 3. & АркаАий (1158-1164) & 13 сентября 1158 г. & Суббота \\
\hline 4. & ИАья (1165-1186) & 11 мая 1165 г. & Вторник \\
\hline 5. & Гавриим (1187-1193) & 31 мая 1187 г. & Воскресенье \\
\hline 6. & Мартирий (1193-1199) & 16 января 1194 г. & Воскресенье \\
\hline \multirow[t]{2}{*}{$7-8}$. & \multirow[t]{2}{*}{$\begin{array}{l}\text { Митрофан (1201-1223, с } \\
\text { перерывами) }\end{array}$} & 14 сентября 1201 г. & $\begin{array}{l}\text { Воздвижение Креста } \\
\text { (пятница) }\end{array}$ \\
\hline & & 17 марта 1219 г. & Воскресенье \\
\hline 9. & Спиридон (1230-1249) & 19 мая 1230 г. & Воскресенье \\
\hline
\end{tabular}

Киев

\begin{tabular}{|l|l|l|l|}
\hline \multirow{2}{*}{ п/п } & Имя архиерея & Настомование & \multicolumn{2}{|l|}{} \\
\cline { 3 - 4 } & и период его правмения & Аата & Аень недеми \\
\hline 1. & Никифор I (1104-1121) & 18 декабря 1104 г. & Воскресенье \\
\hline 2. & Никита (1122-1126) & 15 октября 1122 г. & Воскресенье \\
\hline 3. & Кирим I (1224-1233) & 6 января 1225 г. & $\begin{array}{l}\text { Богоявление } \\
\text { (понедельник) }\end{array}$ \\
\hline
\end{tabular}

Ростов

\begin{tabular}{|l|l|l|l|}
\hline \multirow{2}{*}{ п/п } & Имя архиерея & \multicolumn{2}{|l|}{ Настомование } \\
\cline { 3 - 4 } & и период его правмения & Аата & Аень недеми \\
\hline 1. & Иоанн $(1190-1214)$ & 25 февраля 1190 г. & Воскресенье \\
\hline 2. & Пахомий $(1214-1216)$ & 28 января 1215 г. & СреАа \\
\hline 3. & Киримл II (1231-1261) & 18 мая 1231 г. & Воскресенье \\
\hline
\end{tabular}

Чернигов

\begin{tabular}{|l|l|l|l|}
\hline \multirow{2}{*}{ п/п } & Имя архиерея & Настомование & \\
\cline { 3 - 4 } & и периоА его правмения & Аата & Аень неАели \\
\hline 1. & Феоктист (1113-1123) & 19 января 1113 г. & Воскресенье \\
\hline
\end{tabular}


Переяславль

\begin{tabular}{|l|l|l|l|}
\hline \multirow{2}{*}{ п/п } & Имя архиерея & \multicolumn{3}{|l|}{ Настомование } & \\
\cline { 3 - 4 } & и период его правмения & Аата & Аень недеми \\
\hline 1. & Марк (1125-1134) & 4 октября 1125 г. & Воскресенье \\
\hline
\end{tabular}

Итак, в 13 случаях из 17 вступления архиереев на кафеАры приходились на праздничные Ани - воскресенья (10), Авунадесятые (2) и Великие (1) праздники. К числу послеАних относятся Богоявцение Господне (6 января), ВозАвижение Честного и Животворящего Креста (14 сентября) и Обрезание Господне (1 января). ЕАва ки такая хронология может быть признана случайной. Скорее речь Аолжна иАти о целенаправленном определении Аня проведения церемонии посажения ${ }^{38}$. Поэтому въезА новопоставленного епископа в гороА не быц спонтанным, а подготавливался заранее ${ }^{39}$.

Наличие обозначенной закономерности требует более внимательного отношения к хронологическим указаниям, согласно которым торжественное вступление архиерея на кафедру происходило в будни. Всего установлено 4 таких случая: 3 имеют отношение к Новгородской кафеАре и 1 - к Ростовской. Аумаю, что эти Аатировки нужАаются в дополнительной проверке и объяснении. Амя примера остановимся на Авух таких случаях.

Обратимся к наиболее раннему указанию такого рода - известию о вступлении в Новгород епископа Иоанна Попьяна. Смена святителей на Новгородской кафеАре в начале XII в. описана в НП $\Lambda$ мк. следующим образом:

«В ^ђто 6616. Преставися архиепископъ новгородчкыи Никита, мъсяца генваря въ 31. На весну почаша писати святую Софью. стяжениемъ святого владыкы.

ВАъто 6617.Быстьводавеликавъ Аньпрђ,ивъАеснъ, ивъ Пръпять. Иконцаша трепезницю Печерьскаго манастыря. В то же $九$ бто заложена бысть церкви княземъ Святополкомъ в Киевъ.

В $\Lambda$ Ђто 6618. Прииде в Новъгород архиепископъ Иоанн, мъсяца декабря въ $20 \gg^{40}$.

Как уже отмечалась выше, 20 Аекабря в 1110 г. приходимось на вторник. Это противоречит традиции настолования архиереев в праздничные Ани, следовательно, достоверность указанной Ааты может быть поставлена поА сомнение. Хронология событий 6616-6618 (1108-1110) г., как она преАставлена в новгородском метописании, позволяет подкрепить это сомнение Аополнительными соображениями. Во-первых, бросается в глаза большой временной разрыв межАу смертью епископа Никиты (31 января 1109 г.) и вступлением на кафедру Иоанна Попьяна (20 Аекабря 1110 г.), который составмяет без малого 2 гоАа. МежАу тем внешних затруднений Аля своевременного поставления архиерея на тот момент как будто не прослеживается: митрополичья кафеАра не пустовала, ее занимал Никифор I (1104-1121); что же касается политической обстановки, то она была относительно стабильной. Во-вторых, обращает на себя внимание порядок изложения событий в указанных статьях. Он демонстрирует вполне определенную хронологическую последовательность: епископ Никита умирает в январе; роспись Софии Новгородской начинается весной; высокая вода в Анепре и его

\footnotetext{
${ }^{38}$ К аналогичному выводу недавно пришел А. В. Ааушкин, который показац, что в большинстве случаев торжественные вступцения новопоставценных архиереев на свои кафеАры приходились на праздничные Ани. А это, в свою очереАь, «позволяет говорить об осмысленном выборе времени дмя их проведения и о бытовании на Руси (по крайней мере, с начала XII в., когда появмяются самые ранние Аанные) выраженной празАничной стратегии при их планировании» [Ааушкин, 2019, с. 49]. МежАу тем круг таких праздников определяется исследователем, как кажется, слишком широко. Так, в него включаются не только воскресенья, Авунадесятые и Великие праздники, но и кануны, «кануны канунов» этих торжеств, а также Аругие церковные празАники и даже дни, которые имели календарное значение искмючительно Амя самих участников событий (например, князя и горожан). С Аанной работой Алексея ВАадимировича я познакомияся, когАа текст настоящей статьи уже быи подготовмен к печати.

${ }^{39}$ Аумаю, что в ожидании местной интронизации святитель какое-то время мог находиться за пределами городских стен. Во Владимире-на-Клязьме таким местом был Вознесенский монастырь, который находился недалеко от Золотых ворот. Ср. описание принесения мощей святых в $\Lambda \Lambda$ под 6726 (1218) г. (ПСРА. Т. 1. Стб. 441).

${ }^{40}$ ПСРА. Т. 3. С. 203.
} 
притоках указывает на весенне-летний сезон; закладка князем Святополком церкви в Киеве, как мы знаем из Повести временных мет, происходит в июле; наконец, настолование Иоанна совершается в декабре. Как видно, метописные известия не нарушают очередности годового цикла. Наконец, в-третьих, $\Lambda \Lambda$ и ИА прямо относят закладку княжеской церкви, окончание строительства трапезной в Киево-Печерском монастыре и повышение уровня воды в реках не к 1109 , а к 1108 г.

\begin{tabular}{|c|c|}
\hline$\Lambda \Lambda$ & ИА \\
\hline 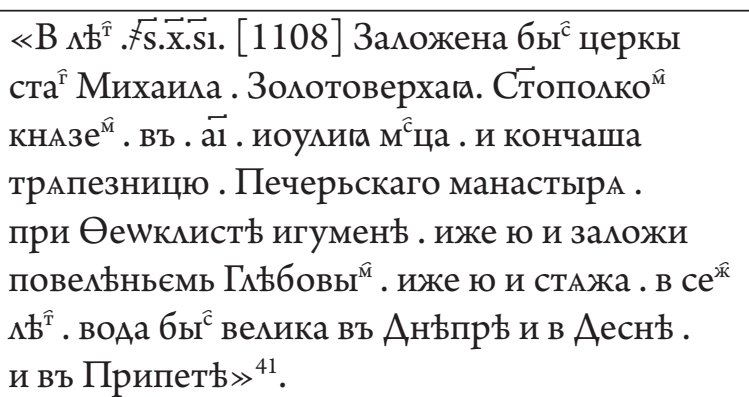 & 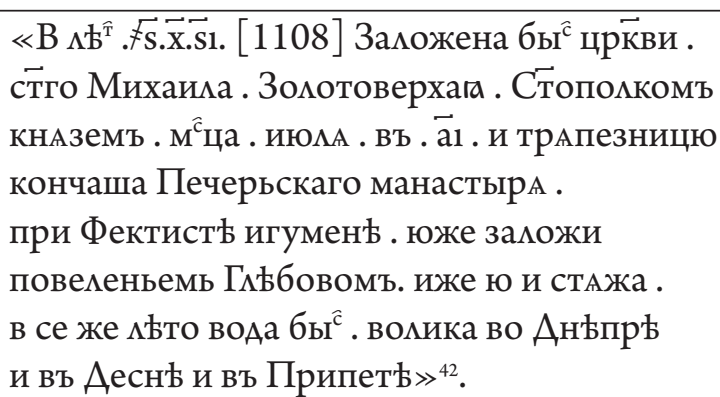 \\
\hline
\end{tabular}

Сказанное позвомяет заключить, что известия 6616-6618 (1108-1110) г. НПА мА. преставление епископа Никиты, роспись Софии Новгородской, паводок в Анепре, Аесне и Припяти, окончание строительства трапезной в Киево-Печерском монастыре, закладка церкви князем Святополком и, наконец, вступление епископа Иоанна Попьяна в НовгороА явмяются событиями одного года, которые быми разнесены сводчиком по разным статьям43. И поскольку Повесть временных мет относит основание Михайловского собора Святополком к 11 июля 1108 г., все обозначенные факты имели место именно в этом году⿰氵丶万 Аанную корректуру, тогАа, во-первых, хронологический разрыв межАу кончиной оАного и поставлением Аругого новгородского владыки сокращается Ао вполне приемлемого срока (9-10 месяцев), а, во-вторых, практика проведения интронизаций в праздничные Ани получает очередное подтверждение, поскольку 20 Аекабря в 1108 г. приходилось на воскресенье ${ }^{45}$. Таким образом, Новгородской епархией Иоанн Попьян начал управлять не 20 декабря 6618 (1110) г., как принято считать, а на Ава года раньше - в $6616(1108)$ г.46

${ }^{41}$ ПСРА. Т. 1. Стб. 283.

${ }^{42}$ ПСРА. Т. 2. Стб. 259.

43 Этот вывод подтвержАают наблюдения Т. В. Гимона, который отмечает, что статьи 6603-6622 (1095-1114) г. в НП Һ были состав ены не ранее 1115 г. «по припоминанию, в момент созАания свода, в качестве новгородского Аопомнения к выпискам из ПВ $\gg[$ Гимон, с. 625-627].

44 Н. Г. Бережков Аатирует кончину Никиты и роспись Новгородской Софии началом 1109 г. ОАнако этот

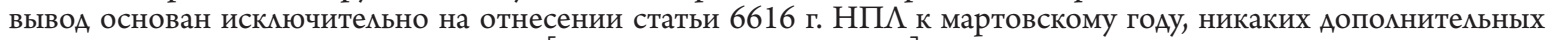
аргументов исследователь не приводит [Бережков, с. 218, 220, 229].

45 По мнению А. В. Ааушкина, выбор 20 декабря в качестве Аня торжественного вступления Иоанна Попьяна в Новгород определялся «большой политической победой», которую в этот Аень восемь мет назаА, в 1102 г., одержали новгородцы и правивший у них князь Мстислав ВАаАимирович. ТогАа горожане отказались подчиниться воле киевского князя Святополка Изяславича (1093-1113) и принять у себя его сына, отстояв таким образом собственного князя [Ааушкин, 2017, с. 72]. Эта точка зрения, хотя и явмяется остроумной, но в свете означенной закономерности не выгляАит Аостаточно убеАительной.

${ }^{46}$ На первый взгляА, преАлагаемой Аатировке противоречит свиАетемьство НПА ми. поА 6638 (1130) г., гАе об уходе с кафедры Иоанна Попьяна говорится: «Того же (ПСРА. Т. 3. С. 207). Вместе с тем указание на 20 мет, в течение которых Иоанн занимах Новгородскую кафедру, отсутствует в аналогичной статье НП А ст. (Там же. С. 22). Это позволяет усматривать в Аанном хронологическом уточнении НП М м. вставку, которая основана на нехитром математическом расчете. Книжник вычем из Ааты отказа Иоанна от епископии дату его прихода в Новгород. Точно так же, как составитель перечня новгородских князей высчитал время правления в Новгороде князя Мстислава ВлаАимировича (20 мет), когда привлек упоминание об этом князе поА 1097 г. и сообщение о его уходе из города поА 1117 г. На самом деме, новгородский стол Мстислав занял в 1095 г. и, следовательно, пребывац на нем в течение 22 мет [Гимон, с. 605]. Аюбопытно, что 20-летний период правления Иоанна обозначен в списке новгородских епископов: «Иван Попьянъ, съАъвъ 20 Аът, отвержеся архиепископья» (ПСРА. Т. 3. С. 473). Аопускаю, что это указание перечня стало источником вставки в текст статьи 6638 (1130) г. НП м м..

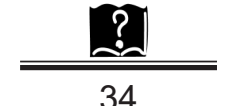


Как сообщает НП А мл., Аатой вступления владыки Аркадия в Новгород было 13 сентября 1158 г. (суббота), канун Авунадесятого праздника ВозАвижения Честного и Животворящего Креста. При этом известно, что из Киева архиерей вернулся еще 11 сентября [Гиппиус, Михеев (в печати)]. Почему же Аркадий не выбрал в качестве времени совершения интронизации 14 сентября - праздник Воздвижения, как это, например, сделал в 1201 г. его преемник архиепископ Митрофан? Аумаю, что Аело здесь не в предписании «чтить 13 сентября как празАник Покмонения честному Кресту» [Ааушкин, 2019, с. 52]. Поскольку, согласно Типикону Великой церкви, покмонение Кресту совершалось в периоА всего предпразднства, которое тогАа начиналось уже 10 сентября. Поэтому, на мой взгляА, мотив был иным. 13 сентября отмечалась память Освящения храма Воскресения Христова в Иерусалиме

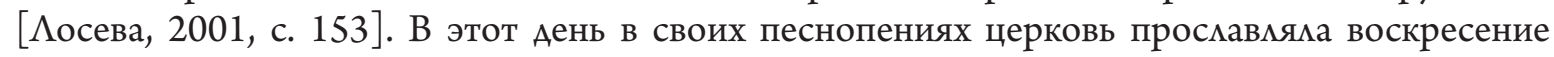
Господа, что сближало его со службой воскресного Аня. Не случайно на Руси этот празАник со временем стали называть «Словущее воскресенье». Чин освящения храма Воскресения быи совершен 13 сентября 335 г. отцами Тирского собора, прибывшими в Иерусалим со всех концов империи. Они же установили ежегодное празднование этого события и отнесли ВозАвижение к 14 сентября. Аюбопытно то, что в 335 г. 13 сентября приходимось на субботу, а 14 сентября - на воскресенье. В 1158 г. эти календарные даты вновь совпали с указанными Анями недели. Это совпадение акцентировало значение праздника Освящения, что вместе с воскресным характером службы повлияло на решение властей приурочить торжественный въезА владыки Аркадия в Новгород к 13 сентября.

Проведенная работа Аает основания утверждать, что в Аревней Руси существовала практика совершения местных интронизаций, которая распространялась и на русских епископов, поставляемых в Киеве, и на митрополитов, прибывающих из Византии. Как и хиротония, посажение архиерея на своей кафедре подготавливалось заранее и совершалось мибо в воскресенье, мибо в Аень большого церковного праздника. Наличие этой закономерности явцяется хорошим инструментом Аля уточнения хронологии событий церковной истории.

\section{Аитература}

Бережков Н. Г. Хрономогия русского метописания. М., 1963.376 с.

Борисов Н. С. К изучению датированных цетописных известий XIV-XV вв. // История СССР. 1983. № 4. C. $124-131$.

Виноградов А. Ю. О времени создания Ростовской епископии (в печати).

Виноградов А. Ю., Желтов М., свлщ. Порядок вступления иерархов на кафеАру в домонгольской Руси и вопросы хронологии первых митрополитов Киевских / / Богословские труАы. 2019. № 49. С. 155-169. Высоикий С. А. Средневековые надписи Софии Киевской. По материалам граффити XI-XVII вв. Киев, $1976.455 \mathrm{c}$.

Гимон Т. В. События XI - начала XII в. в новгородских метописях и перечнях // Аревнейшие госуАарства Восточной Европы, 2010 гоА: Предпосылки и пути образования Аревнерусского госуАарства. М., 2012. C. 584-703.

Гиппиус А.А., Михеев С. М. Аетописная наАпись-граффито 6666 гоАа. Из своАа Аревних наАписей на стенах Новгородского Софийского собора // НовгороА и НовгороАская земля. Письменность и книжность. Материалы научной конференции. Великий НовгороА, 24-26 сентября 2019 г. Новгородский музейзаповедник. Великий НовгороА, 2021 (в печати).

Евгений (Болховитинов), митр. Киевский и Галиикий. Описание Киево-Софийского собора и Киевской иерархии. Киев, 1825. [4], 291, [1] с.

Желтов М., свящ. Интронизация // Православная энциклопедия. М., 2010. Т. 23. С. 124-131.

Карпов А. Ю. Русская Церковь ХІ-ХІІІ вв. Биографический словарь. М., 2016. 472 с.

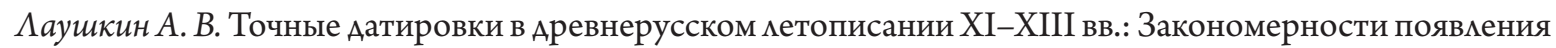
// Восточная Европа в Аревности и средневековье: Время источника и время в источнике. XVI Чтения

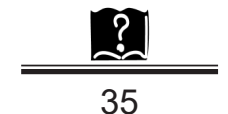


памяти чмена-корреспондента АН СССР В. Т. Пашуто. Москва, 14-16 апремя 2004 г. Материалы конференции. М., 2004. С. 101-104.

Ааушкин А. В. Входы новопоставленных новгородских вцадык в свой гороА: хронологический аспект (XII-XIII вв.) // Аревняя Русь. Вопросы медиевистики. 2017. № 3 (69). С. 71-72.

Ааушкин А. В. ВхоА новопоставленного епископа Пахомия в Ростов 28 января 1215 года: выбор Аня Аля торжественной церемонии // Вестник Православного Свято-Тихоновского гуманитарного университета. Серия II: История. История Русской Православной Церкви. 2019. Вып. 89. С. 49-66.

Аосева О. В. Русские месяцесловы XI-XIV веков. М., 2001. 420 с.

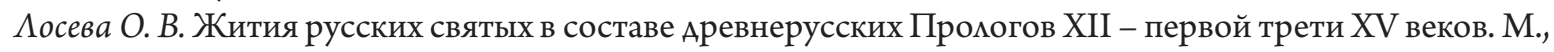
2009. 466 c.

Макарий (Булгаков), митр. Московский и Коломенский. История Русской церкви. М., 1995. Кн. 2. История Русской церкви в период совершенной зависимости ее от Константинопольского патриарха. 702, [1] с. Неселовский А. 3. Чины хиротесий и хиротоний (Опыт историко-археологического исследования). Каменец-Подольск, 1906. 375 с.

Поппэ А. Митрополиты киевские и всея Руси (988-1305 гг.) // Подскальски Г. Христианство и богосмовская митература в Киевской Руси (988-1237 гг.). СПб., 1996. С. 446-471.

Турилов А. А. Иларион // Православная энцикмопедия. М., 2010. Т. 22. С. 122-126.

Щапов Я. Н. ГосуАарство и церковь Аревней Руси в X-XIII вв. М., 1989. 228, [3] с.

\section{References}

Berezhkov, N. G. Khronologiya russkogo letopisaniya [Chronology of the Russian Annals]. Moscow, 1963. $376 \mathrm{p}$.

Borisov, N. S. K izucheniyu datirovannykh letopisnykh izvestii XIV-XV vv. [To the Study of Dated Chronicle News of the $14^{\text {th }}-15^{\text {th }}$ Centuries]. In Istoriya SSSR. 1983. No. 4. Pp. 124-131.

Evgenii (Bolkhovitinov), Metropolitan Kievsky i Galitsky. Opisanie Kievo-Sofiiskogo sobora i Kievskoi ierarkhii [Description of St. Sophia Cathedral and the Kiev Hierarchy]. Kiev, 1825. [4], 291, [1] p.

Gimon, T. V. Sobytiya XI - nachala XII v. v novgorodskikh letopisyakh i perechnyakh [Events of the 11th Beginning of the $12^{\text {th }}$ Century in the Novgorod Chronicles and Lists]. In Drevneishie gosudarstva Vostochnoi Evropy, 2010 god: Predposylki i puti obrazovaniya Drevnerusskogo gosudarstva. Moscow, 2012. Pp. 584-703.

Gippius, A. A., Mikheev, S. M. Letopisnaya nadpis'-graffito 6666 goda. Iz svoda drevnikh nadpisei na stenakh Novgorodskogo Sofiiskogo sobora [The Chronicle Inscription-graffiti of 6666. From the Corpus of Ancient Inscriptions on the Walls of St. Sophia Cathedral in Novgorod]. In Novgorod i Novgorodskaya zemlya. Pis'mennost' iknizhnost'. Materialy nauchnoi konferentsii. Velikii Novgorod, 24-26 sentyabrya 2019g. Novgorodskii muzei-zapovednik. Veliky Novgorod, 2021 (in print).

Karpov, A. Yu. Russkaya Tserkov' XI-XIII vv. Biograficheskii slovar' [Russian Church of the $11^{\text {th }}-13^{\text {th }}$ Centuries. Biographical Dictionary]. Moscow, 2016. 472 p.

Laushkin, A. V. Tochnye datirovki v drevnerusskom letopisanii XI-XIII vv.: Zakonomernosti poyavleniya [Exact Dates in the Old Russian Annals of the $11^{\text {th }}-13^{\text {th }}$ Centuries: Patterns of Occurrence]. In Vostochnaya Evropa $v$ drevnosti $i$ srednevekov'e: Vremya istochnika i vremya $v$ istochnike. XVI Chteniya pamyati chlenakorrespondenta AN SSSR V. T. Pashuto. Moskva, 14-16 aprelya 2004 g. Materialy konferentsii. Moscow, 2004. Pp. 101-104.

Laushkin, A. V. Vkhody novopostavlennykh novgorodskikh vladyk $\mathrm{v}$ svoi gorod: khronologicheskii aspekt (XII-XIII vv.) [Entries of the Newly Appointed Novgorod Hierarchs to Their City: Chronological Aspect $\left(12^{\text {th }}-13^{\text {th }}\right.$ Centuries) ]. In Drevnyaya Rus'. Voprosy medievistiki. 2017. No. 3 (69). Pp. 71-72.

Laushkin, A. V. Vkhod novopostavlennogo episkopa Pakhomiya v Rostov 28 yanvarya 1215 goda: vybor dnya dlya torzhestvennoi tseremonii [Entry of the Newly Appointed Bishop Pachomius to Rostov on January 28, 1215: Choosing the Day for the Solemn Ceremony]. In Vestnik Pravoslavnogo Svyato-Tikhonovskogo gumanitarnogo universiteta. Seriya II: Istoriya. Istoriya Russkoi Pravoslavnoi Tserkvi. 2019. Issue 89. Pp. 49-66. Loseva, O. V. Russkie mesyatseslovy XI-XIV vekov [Russian Mesyatseslovs of the $11^{\text {th }}-14^{\text {th }}$ Centuries]. Moscow, 2001.420 p.

Loseva, O. V. Zhitiya russkikh svyatykh v sostave drevnerusskikh Prologov XII - pervoi treti XV vekov [Lives of Russian Saints in the Old Russian Prologues of the $12^{\text {th }}$ - First Third of the $15^{\text {th }}$ Centuries]. Moscow, 2009. $466 \mathrm{p}$.

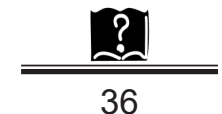


Makarii (Bulgakov), Metropolitan Moskovsky i Kolomensky. Istoriya Russkoi tserkvi [History of the Russian Church]. Moscow, 1995. Kn. 2. Istoriya Russkoi tserkvi v period sovershennoi zavisimosti ee ot Konstantinopol'skogo patriarkha. 702, [1] p.

Neselovskii, A. Z. Chiny khirotesii i khirotonii (Opyt istoriko-arkheologicheskogo issledovaniya) [Ranks of Ordinations (Attempt of Historical and Archaeological Research)]. Kamenets-Podolsk, 1906. 375 p.

Poppe, A. Mitropolity kievskie i vseya Rusi (988-1305 gg.) [Metropolitans of Kiev and All Russia (9881305)]. In Podskal'ski G. Khristianstvo i bogoslovskaya literatura v Kievskoi Rusi (988-1237 gg.). Saint Petersburg, 1996. Pp. 446-471.

Shchapov, Ya. N. Gosudarstvo i tserkov' Drevnei Rusi v X-XIII vv. [State and Church of Old Rus in the $10^{\text {th }}-$ $13^{\text {th }}$ Centuries]. Moscow, 1989. 228, [3] p.

Turilov, A. A. Ilarion [Hilarion]. In Pravoslavnaya entsiklopediya. Moscow, 2010. Vol. 22. Pp 122-126.

Vinogradov, A. Yu. O vremeni sozdaniya Rostovskoi episkopii [About the Time of Creation of the Rostov Bishopric] (in print).

Vinogradov, A. Yu., Zheltov, M., priest. Poryadok vstupleniya ierarkhov na kafedru v domongol'skoi Rusi i voprosy khronologii pervykh mitropolitov Kievskikh [The Order of Hierarchs Entry to the See in preMongol Rus and Issues of Chronology of the First Metropolitans of Kiev]. In Bogoslovskie trudy. 2019. No. 49. Pp. 155-169.

Vysotskii, S. A. Srednevekovye nadpisi Sofii Kievskoi. Po materialam graffiti XI-XVII vv. [Medieval Inscriptions of St. Sophia of Kiev. Based on Graffiti of the $11^{\text {th }}-17^{\text {th }}$ Centuries]. Kiev, 1976. 455 p.

Zheltov, M., priest. Intronizatsiya [Enthronement]. In Pravoslavnaya entsiklopediya. Moscow, 2010. T. 23. Pp. 124-131.

Yury A. Artamonov

Moscow University of the Ministry of Internal Affairs of Russia named after V. Ya. Kikotya, Institute of Russian History of the Russian Academy of Sciences, Institute of World History of the Russian Academy of Sciences, Moscow, Russia

\section{ABOUT THE TIME OF HIERARCH ENTHRONEMENT IN OLD RUS}

The analysis of sources leads the author to the conclusion that, in Old Rus, there was a practice of local enthronement of both, bishops of Rus origin consecrated in Kiev, and metropolitans arriving from Byzantium. As the consecration itself, the enthronement was prepared in advance and took place either on Sunday, or on the day of an important ecclesiastical feast. Such a regularity implies that we must treat with caution any evidence that a bishop was enthroned on a weekday. Basing on this conclusion, as well as on some other observations, the author argues that Bishop Ioann I (Popian) of Novgorod was enthroned not on the $20^{\text {th }}$ of December, 1110 , as it is generally believed, but on the $20^{\text {th }}$ of December, 1108, which was Sunday.

Keywords: enthronement, consecration, bishop, metropolitan, Old Rus dioceses, Old Rus Church, chronology of Rus chronicles 